\title{
Role of trastuzumab in the management of HER2-positive metastatic breast cancer
}

REVIEW

This article was published in the following Dove Press journal:

Breast Cancer:Targets and Therapy

23 November 2010

Number of times this article has been viewed

\author{
Andrea Milani ${ }^{1,2}$ \\ Filippo Montemurro' \\ Luisa Gioeni' \\ Massimo Aglietta ${ }^{1,2}$ \\ Giorgio Valabrega ${ }^{1,2}$ \\ 'Oncological Department, Medical \\ Oncology, Institute for Cancer \\ Research and Treatment (IRCC), \\ Candiolo, Torino, Italy; ${ }^{2}$ University \\ of Turin Medical School, Department \\ of Biomedical Sciences and Human \\ Oncology, Turin, Italy
}

\begin{abstract}
Breast cancer is a major health issue in developed countries. Overexpression of HER2, a member of epidermal growth factor receptor family, occurs in $20 \%-30 \%$ of breast cancers. HER2 drives the cancer cells to develop a more aggressive phenotype, to metastasize to viscera and central nervous system, and to be less sensitive to chemotherapeutic agents. Trastuzumab $\left(\right.$ Herceptin $^{\circledR}$ ) is a monoclonal antibody directed against the extracellular domain of HER2. As single agent or with chemotherapy, trastuzumab improves survival of HER2-positive breast cancers. In the past years, trastuzumab has completely revolutionized the scenario of the treatment of HER2-positive breast cancer, representing one of the most remarkable examples of targeted therapy in oncology. However, issues such as the best chemotherapeutic companion to associate with trastuzumab, cardiac toxicities, and clinical resistance still require tremendous efforts by researchers. Here, we review pharmacology, efficacy studies, and toxicities of trastuzumab in metastatic breast cancer. Moreover, we provide some insights on resistance to therapy. Finally, we briefly discuss trastuzumab's place in the clinical setting.
\end{abstract}

Keywords: HER2, trastuzumab, breast cancer, cardiotoxicity, resistance

\section{Introduction to HER2-positive metastatic breast cancer management}

Breast cancer is a major public health issue in developed countries in terms of morbidity, mortality, and costs. ${ }^{1}$ Integrating multiple strategies such as early diagnosis, surgery, radiotherapy, and chemotherapy has resulted in decreased mortality in previous years. ${ }^{2}$ A part of the merit should be given to a better understanding of mechanisms underlying breast cancer development. This, in turn, has resulted in the identification of druggable molecular targets in cancer cells.

Epidermal growth factor receptor 2 (ErbB2/HER2) is a ligandless tyrosine kinase receptor, member of the epidermal growth factor receptor (EGFR) family and is overexpressed in $20 \%-30 \%$ of breast cancers. ${ }^{3,4}$ Its overexpression distinguishes a subgroup of breast cancers characterized by increased aggressiveness, mortality, and high sensitivity to anthracyclines. ${ }^{5}$ HER2 overexpression is primarily associated with amplification of the HER $2 /$ neu $^{6}{ }^{6}$

Its activation follows dimerization with other tyrosine kinase receptors belonging to the EGFR family (EGFR, HER3, or HER2 itself) or to other families, such as insulin-like growth factor receptor 1 (IGF-1R). ${ }^{7,8}$ Dimerization activates downstream signaling cascades, including mitogen-activated protein kinase (MAPK) and phosphoinositide 3-kinase (PI3K) pathways, which promotes cellular proliferation, survival, migration, invasion, and differentiation. ${ }^{8}$ 
Several features render HER2 an optimal target for breast cancer treatment: ${ }^{9}$

1. HER2 overexpression strongly correlates with tumor progression.

2. HER2-overexpressing breast cancer cells become almost totally dependent for their survival on signaling network cascades triggered by HER 2 .

3. The level of expression of HER2 in normal adult tissue is much lower than in cancer cells that overexpress the protein.

For these reasons, research has focused on developing HER2 inhibitors as potential anticancer agents. The first of such agents registered for clinical use was trastuzumab $\left(\right.$ Herceptin $\left.^{\circledR}\right)$.

\section{HER2 status assessment}

Clinical studies have shown that women who most benefit from trastuzumab have high levels of HER2 expression. ${ }^{10}$ Aspects regarding the best way to assess HER2 status have been largely discussed, and clinical implications have been outlined in recent guidelines. ${ }^{11}$

Currently, HER2 status is assessed by immunohistochemistry (IHC), fluorescent in situ hybridization (FISH), and chromogenic in situ hybridization (CISH).

IHC identifies HER2 overexpression on the cell membrane. Results are usually expressed using a semiquantitative scoring system ranging from $0+$ (no expression) to $3+$ (high expression). Tumors that show no $(0+)$ or low levels $(1+)$ of expression are considered HER2negative; vice-versa tumors that show high levels (3+) of expression should be considered as HER2-positive. This method is economically advantageous and readily available, but suffers from low sensitivity and high interobserver variability. ${ }^{12}$

FISH detects HER2 gene amplification and is more specific and sensitive than IHC. ${ }^{6,13}$ FISH offers quantitative results on the number of HER2 gene copies/centromere. Another FDA-approved method to assess HER2 gene amplification is CISH. CISH is very similar to FISH but utilizes conventional peroxidase or alkaline phosphatase reactions visualized under a standard bright-field microscope. Both gene amplification detected by FISH or CISH and protein expression by IHC are commonly used as initial test to assess HER2 status. Equivocal cases, defined as either IHC 2+ or FISH/CISH ratio of 1.8-2.2 or average HER2 gene copy number four to six signals/nucleus for test systems without an internal control probe, undergo further testing with the alternative method.
A recent report by the ASCO/CAP demonstrated that, after a rigorous standardization, concordance between HER2 $3+$ and gene amplification detection is about $98 \%-98.5 \% .^{14}$ Phase II and III trials in metastatic disease showed that trastuzumab has relevant clinical activity against HER2-positive metastatic breast cancer. In the next paragraphs, we will summarize pharmacological issues, clinical activity, toxicities, and some biology on resistance to trastuzumab.

\section{Review of mode of action, pharmacology, and pharmacokinetics of trastuzumab in breast cancer Mechanism of action}

Trastuzumab is a humanized IgG1k monoclonal antibody that selectively binds to the extracellular domain (ECD) of the human ErbB2 protein HER2.,15 In vivo, the most relevant mechanism of action is antibody-dependent cellular cytotoxicity (ADCC). In brief, natural killer (NK) cells are able to bind trastuzumab on HER2-positive cancer cells through an Fc receptor. Upon binding, NK cells are able to induce cancer cell death by releasing lytic enzymes. ${ }^{16}$ Trastuzumab triggers antibody-dependent cell-mediated cytotoxicity (ADCC) principally by activating Fc $\gamma$ receptor on NK cells. ${ }^{16,17}$ Unfortunately, clinical trials failed to show clinical benefit derived from association of trastuzumab with immune-modulating agents, such as IL-2, despite NK cell expansion with enhanced in vitro targeted killing of HER2expressing cells. ${ }^{18}$

Musolino et a ${ }^{19}$ studied a population of 54 patients with HER2-amplified breast cancer who have received taxanes plus trastuzumab for metastatic disease and evaluated genotypes for the Fc $\gamma$ RIIIa-158 valine(V)/phenylalanine(F),

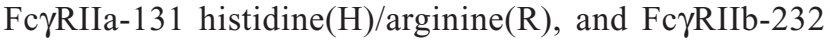
isoleucine(I)/threonine( $\mathrm{T}$ ) polymorphisms. Interestingly, the authors showed that the Fc $\gamma$ RIIIa-158 V/V genotype, alone and in combination with the Fc $\gamma \mathrm{RIIa}-131 \mathrm{H} / \mathrm{H}$ genotype, was significantly associated with better response rate and progression-free survival (PFS) to trastuzumab compared with other Fc $\gamma R$ genotypes. This study supports the hypothesis that Fc $\gamma \mathrm{R}$ polymorphisms play a role in trastuzumab-mediated ADCC and predict response to trastuzumab.

At ASCO 2009, Tamura et $\mathrm{al}^{20}$ presented preliminary results of a similar study on a population of 19 operable and 36 metastatic patients with HER2-overexpressing breast cancer treated with trastuzumab-containing chemotherapy, showing that Fc $\gamma$ RIIa-131 H/H genotype was significantly 
correlated with pCR $(P=0.0034)$ and OR $(P=0.037)$, whereas FcyRIIIa-158V/V genotype had a tendency to be correlated with pCR $(P=0.067)$ and was significantly correlated with $\mathrm{OR}(P=0.037)$.

Similarly to trastuzumab, it was shown that Fc $\gamma$ receptor polymorphisms play a role also in differential response to other antibodies, such as cetuximab in colorectal cancer. ${ }^{21,22}$

Furthermore, impaired T cell and NK function can possibly contribute to trastuzumab resistance.

Several studies showed that a reduced number or impaired function of NK cells is correlated with shortened response to trastuzumab,,$^{23,24}$ and often, this is due to surgical or chemoand radiotherapy. ${ }^{25}$

In vitro, trastuzumab induces the following perturbations in cancer cells: HER2 receptor downregulation and degradation and subsequent attenuation of downstream signaling, ${ }^{26}$ G0 arrest; ${ }^{27}$ and induction of apoptosis. ${ }^{28}$ The mechanisms of action of trastuzumab are summarized in Figure 1.

\section{Pharmacology}

The pharmacokinetics of trastuzumab has been studied in patients with metastatic breast cancer and subsequently in early-stage breast cancer patients in addition to adjuvant chemotherapy. Short-duration intravenous infusions of $10,50,100,250$, and $500 \mathrm{mg}$ of trastuzumab once weekly demonstrated dose-dependent pharmacokinetics. The half-life averages 1.1 (using a one-compartment model at $10 \mathrm{mg}$ ) and 23 (using a two-compartment model at $500 \mathrm{mg}$ ) days at the 10- and 500-mg dose levels, respectively. At the highest weekly dose studied (500 mg), mean peak serum concentration was $377 \mu \mathrm{g} / \mathrm{mL}^{29}$

In clinical trials, where a loading dose of $4 \mathrm{mg} / \mathrm{kg}$ trastuzumab followed by a subsequent weekly dose of $2 \mathrm{mg} / \mathrm{kg}$ was used, the mean clearance was $0.225 \mathrm{~L} /$ day. Between weeks 16 and 32, trastuzumab serum concentrations reached a steady state with a mean through and peak concentrations of approximately $79 \mu \mathrm{g} / \mathrm{mL}$ and $123 \mu \mathrm{g} / \mathrm{mL}$, respectively. ${ }^{30}$

Population pharmacokinetics analysis of data from the initial phase I, II, and III studies suggested a half-life of 28.5 days, which justifies an every 3 -week schedule: this long half-life is similar to that of endogenous IgG1 immunoglobulins (23 days). ${ }^{31}$ Moreover, it was shown that trastuzumab administered every three weeks has pharmacokinetics similar to the weekly regimen; ${ }^{32}$ the washout period is up to 20 weeks (95\% confidence interval, 18-24 weeks); steady state pharmacokinetics should be reached by approximately 20 weeks (95\% confidence interval, 18-24 weeks).
Trastuzumab's volume of distribution is approximately that of serum volume $(44 \mathrm{~mL} / \mathrm{kg}){ }^{29}$

The distribution of trastuzumab does not seem to be altered by age or serum creatinine (up to $2.0 \mathrm{mg} / \mathrm{dL}$ ), although formal interaction studies have not been performed. ${ }^{33}$

Monoclonal antibodies can face added difficulties due to their high molecular weights, target specificity, kinetics of metabolism and internalization, as well as the patterns of antigen expression in combination with target-binding affinity. The high molecular weight (145.5 KDa) and binding affinity of trastuzumab, in combination with microenvironmental factors, may limit its distribution and efficacy. ${ }^{34,35}$ Tumor vascular abnormalities contribute to inefficient drug penetration by creating regions of irregular or intermittent blood flow, slowed interstitial fluid velocity, and often elevated interstitial fluid pressure. ${ }^{36,37}$ Notwithstanding considerable heterogeneity in trastuzumab distribution, the ability of trastuzumab to penetrate through tissues seems to be relatively efficient. ${ }^{35}$

\section{Trastuzumab and blood-brain barrier}

Because of its high molecular weight, trastuzumab is not able to cross an intact blood-brain barrier (BBB). However, the patients with brain metastases (BM) are commonly treated as indicated with at least one of the following treatment modalities: whole brain radiotherapy (WBRT), stereotactic radiotherapy, and metastasectomy.

These treatments for BM could disrupt the BBB and subsequently make it possible to deliver trastuzumab into the central nervous system (CNS). ${ }^{38}$ In a pilot study, Stemmler et $\mathrm{al}^{39}$ have evaluated the ability of trastuzumab to penetrate the BBB measuring trastuzumab levels in the serum and in cerebrospinal fluid of HER2-positive breast cancer patients with BM. The authors demonstrated that, at different time points, trastuzumab levels are increased in cerebrospinal fluid when $\mathrm{BBB}$ is impaired (eg, in the presence of meningeal carcinomatosis or radiotherapy).

\section{Efficacy studies in metastatic breast cancer Trastuzumab as single agent or in combination with chemotherapy}

Phase II trials of single-agent trastuzumab showed overall response rate of $11.6 \%-15 \%$ in women with heavily pretreated HER2-positive metastatic breast cancer ${ }^{30,40}$ and of $35 \%$ in the first-line setting ${ }^{33}$ and, very interestingly, median duration of response was similar to the one that can be 


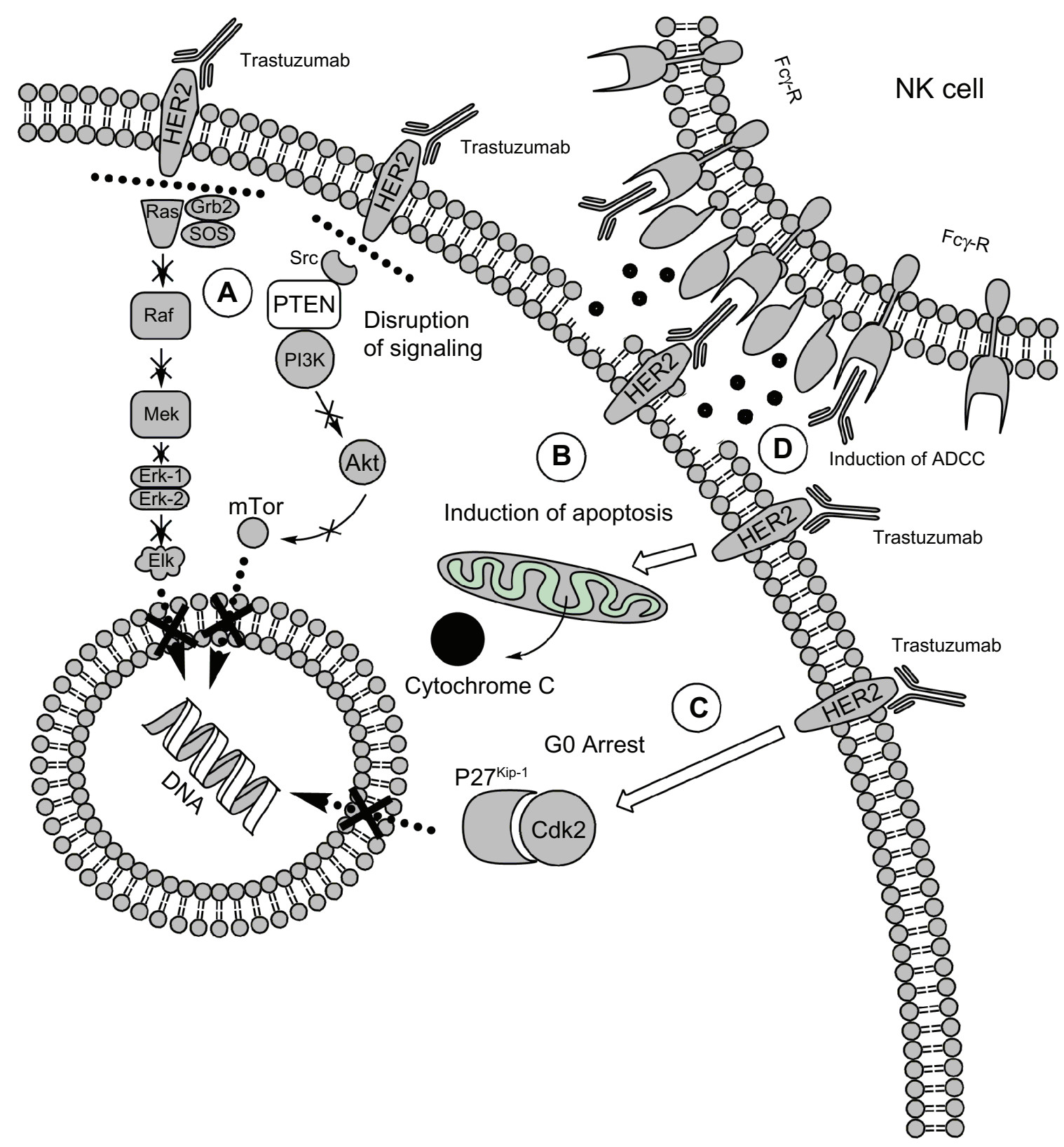

Figure I Mechanisms of action of trastuzumab. A) In vitro, trastuzumab is able to disrupt signaling through PI3K/Akt and MAPK signaling pathways; causes a disruption of the binding of Src to HER2, allowing PTEN to inhibit Akt B); induces apoptosis of target cells and C) cell cycle arrest in G0-GI phase, via modulating the cyclin-dependent kinase (CDK) inhibitor 27 Kipl. D) In vivo, trastuzumab binds the Fc $\gamma$ receptor on NK cells and triggers the antibody-dependent cell-mediated cytotoxicity (ADCC). Abbreviations: HER2, human epidermal growth factor receptor 2; NK, natural killer; FcyR, fragment crystallizable region gamma receptor; Grb2, growth factor receptorbound protein 2; SOS, son of sevenless protein; Ras, small GTPase protein; Raf, Mek, and Erk, serine/threonine-protein kinases; Elk, transcription factor; Src, Rous sarcoma tyrosine kinase; PTEN, phosphatase and tensin homolog; PI3K, phosphatidylinositol 3-kinases; Akt, serine/threonine protein kinase; mTor, mammalian target of rapamycin; p27 ${ }^{\text {Kip-I }}$, cyclin-dependent kinase inhibitor IB; Cdk2, cyclin-dependent kinase 2a.

obtained with the association with chemotherapy. The firstline study also showed that dose escalation does not increase overall response rate.

These studies led to the pivotal clinical trial, H0648g, which started in 1995 and enrolled 469 patients with previously untreated, HER2-positive metastatic breast cancer. Patients were randomly assigned to receive chemotherapy (either doxorubicin or epirubicin combined with cyclophosphamide, in patients without previous exposure to adjuvant anthracyclines, or paclitaxel in patients who had previously received adjuvant anthracyclines) with or without trastuzumab. The primary end point of this study was median time to disease progression, which was 4.6 months in patients who received chemotherapy alone and 7.4 months for those who received chemotherapy plus trastuzumab $(P<0.001)$; trastuzumab was also associated 
with an increase in objective response rate $(50 \%$ versus $32 \% ; P<0.001$ ), longer duration of response (median 9.1 versus 6.1 months; $P<0.001$ ), and longer median survival (25.1 versus 20.3 months; $P=0.046) .{ }^{10}$ A subsequent randomized phase II trial of docetaxel with trastuzumab or docetaxel alone published in 2005 also showed an improved overall response rate $(61 \%$ versus $34 \% ; P=0.0002)$, better overall survival (median 31.2 versus 22.7 months; $P=0.0325$ ), and longer time to disease progression (median 11.7 versus 6.1 months; $P=0.0001$ ) for the association arm..$^{41}$ Various non-randomized phase II trials have shown the efficacy and safety of trastuzumab in combination with most other chemotherapies (also including liposomal anthracyclines) for treatment of breast cancer. Currently, it is unclear whether any specific chemotherapeutic drug or class can be particularly effective in combination with trastuzumab (Table 1). ${ }^{42-58}$

\section{Second-line treatment}

Continuation versus discontinuation of trastuzumab after disease progression is controversial among oncologists. Retrospective studies have had conflicting results. ${ }^{59,60}$ The only available randomized phase III trial which apparently supports continuation of trastuzumab in association with capecitabine in patients who have progressed while receiving trastuzumab ${ }^{61}$ prematurely closed accrual and, most importantly, was biased by significant unbalances in treatment arms.

Lapatinib is an orally bioavailable, small-molecule dual HER1/HER2 tyrosine kinase inhibitor. In patients whose disease has progressed after prior treatment with an anthracycline, a taxane, and trastuzumab, a randomized, controlled phase III study supports the use of the lapatinib in combination with capecitabine. ${ }^{62}$ The median time to progression for patients who received capecitabine plus lapatinib was 8.4 months compared with 4.4 months in women who received capecitabine monotherapy (HR 0.49; 95\% CI $0.34-0.71 ; P<0.001)$, and there was a possibility of improved overall response $(22 \%$ versus $14 \% ; P=0.09)$. Phase II data also show modest activity of lapatinib either alone or in combination with capecitabine for the treatment of brain metastases in patients with HER2-positive breast cancer. ${ }^{63}$ Trastuzumab and lapatinib without chemotherapy is another treatment option in women with HER2-positive breast cancer who have disease progression while receiving trastuzumab. In a randomized phase III study, 296 patients with metastatic disease who had progression on trastuzumab treatment were randomly assigned to receive lapatinib plus trastuzumab or lapatinib alone. Patients were heavily pretreated and had received a median of six prior anticancer regimens and a median of three prior lines of trastuzumab. In the combination group, compared with lapatinib monotherapy, the median progression free survival (PFS) was 12 weeks versus 8.1 weeks and the overall clinical benefit rate was $24.7 \%$ versus $12.4 \%(P=0.01){ }^{64}$

\section{Trastuzumab and endocrine therapy}

About $40 \%-50 \%$ of HER2-positive tumors coexpress hormone receptors (HR). Coexpression of HER2 in HR-positive tumors is associated with reduced efficacy of endocrine therapy ${ }^{65,66}$ One of the most credited mechanism that has been proposed to explain endocrine resistance is cross-talk between the estrogen receptor (ER) and HER family pathways. ${ }^{67,68}$ Hyperactive HER2 or EGFR can activate the ER directly, in the absence of its natural ligand. This explains not only resistance to selective estrogen receptor downmodulators, but also to aromatase inhibitors. Combined blocking of both pathways has been tested in two randomized clinical trials in patients with previously untreated HER2-/ HR-positive advanced breast cancer. ${ }^{69-71}$

The trastuzumab in dual HER2-positive, ER-positive metastatic breast cancer (TAnDEM) trial randomly assigned women with HER2-positive and hormone-receptor-positive untreated metastatic breast cancer to anastrozole with or without trastuzumab. This study found a significant advantage for both response rate $(6.8 \%$ versus $20.3 \% ; P=0.018)$ and PFS (2.4 versus 4.8 months; $P=0.0016)$ with the addition of trastuzumab. ${ }^{69}$

A similar study of the same population of patients randomly assigned women to receive letrozole plus lapatinib or letrozole alone and showed increased PFS (8.2 months versus 3 months; HR $0.71 ; P=0.019)$ and higher overall response rate $(28 \%$ versus $15 \% ; P=0.021) .{ }^{70}$ In conclusion, in postmenopausal women with hormone-receptor positive, HER2-positive, metastatic breast cancer with low disease burden, the combination of anti-HER2-targeted therapy with an aromatase inhibitor is a reasonable option.

\section{Review of the mechanisms of trastuzumab resistance in breast cancer}

The outstanding results obtained with the introduction of trastuzumab in the clinical management of HER2-overexpressing breast cancer are limited by primary and acquired resistance to the antibody. Currently, there is no widely accepted definition of resistance. In the clinical setting, resistance is defined as progressive disease. ${ }^{72}$ 
Table I Results of the main studies of trastuzumab with chemotherapy in metastatic breast cancer

\begin{tabular}{|c|c|c|c|c|c|}
\hline Author & Study & Drugs & No. of patients & $\begin{array}{l}\text { Patient's } \\
\text { characteristics }\end{array}$ & Main results \\
\hline Slamon et al ${ }^{10}$ & Phase III & $\begin{array}{l}\text { Taxanes or anthracyclines } \pm \\
\text { wTrastuzumab }\end{array}$ & 469 & $\begin{array}{l}\text { Previously untreated } \\
\text { HER2+ metastatic BC }\end{array}$ & $\begin{array}{l}\text { mTTP (chemo }+ \text { trastuzumab } \\
\text { versus chemo) } 7.4 \text { versus } \\
4.6 \text { months }(P=0.00 \mathrm{I}) \\
\text { OS (chemo }+ \text { trastuzumab } \\
\text { versus chemo) } 25 . \mathrm{I} \text { versus } \\
20.3 \text { months }(P=0.0 \mathrm{I})\end{array}$ \\
\hline Marty et $\mathrm{al}^{41}$ & R phase II & $\begin{array}{l}\text { Docetaxel } 100 \mathrm{mg} / \mathrm{m}^{2}+ \\
\text { q3wTrastuzumab versus } \\
\text { docetaxel } 100 \mathrm{mg} / \mathrm{m}^{2} \text { alone }\end{array}$ & 186 & $\begin{array}{l}\text { Previously untreated } \\
\text { HER2+ metastatic BC }\end{array}$ & $\begin{array}{l}\text { ORR } 61 \% \text { versus } 34 \% \\
(P=0.0002) \\
\text { OS } 32 \text { versus } 22 \text { months } \\
(P=0.0325)\end{array}$ \\
\hline Esteva et $\mathrm{al}^{43}$ & Phase II & $\begin{array}{l}\text { Docetaxel } 35 \mathrm{mg} / \mathrm{m}^{2} / \mathrm{w}+ \\
\text { wTrastuzumab }\end{array}$ & 30 & HER2+ metastatic BC & $\begin{array}{l}\text { ORR } 63 \% \\
(95 \% \mathrm{Cl}=44 \%-80 \%)\end{array}$ \\
\hline Sledge $e^{46}$ & Phase II & $\begin{array}{l}\text { Gemcitabine } 1200 \mathrm{mg} / \mathrm{m}^{2} \text { days } \\
\text { I,8 q2 I + } \\
\text { paclitaxel } 175 \mathrm{mg} / \mathrm{m}^{2} \text { day I q2 } \mathrm{I}+ \\
\text { wTrastuzumab }\end{array}$ & 42 & $\begin{array}{l}\text { Previously untreated } \\
\text { HER2+ metastatic BC }\end{array}$ & ORR $67 \%$ mTTP 9 months \\
\hline Bianchi et $\mathrm{al}^{47}$ & Phase II & $\begin{array}{l}\text { Cohort I: } 3 \text { cycles of } \\
\text { DT }\left(60 / / 50 \mathrm{mg} / \mathrm{m}^{2}\right) \text { and } \\
\text { wTrastuzumab followed by } \\
9 \text { cycles of T }\left(80 \mathrm{mg} / \mathrm{m}^{2}\right) \text { and } \\
\text { wTrastuzumab } \\
\text { Cohort } 2: 3 \mathrm{cycles} \text { of DT } \\
\left(60 / 150 \mathrm{mg} / \mathrm{m}^{2}\right) \text { followed by } \\
9 \text { cycles of T }\left(80 \mathrm{mg} / \mathrm{m}^{2}\right) \text { and } \\
\text { wTrastuzumab }\end{array}$ & $\begin{array}{l}\text { Cohort I: } 16 \\
\text { Cohort 2: } 16\end{array}$ & $\begin{array}{l}\text { Previously untreated } \\
\text { HER2+ advanced and } \\
\text { metastatic BC }\end{array}$ & $\begin{array}{l}\text { ORR (for both cohorts) } \\
87.5 \% \\
(95 \% \mathrm{Cl}=61.65 \%-98.45 \%)\end{array}$ \\
\hline Pegram et al $\left.\right|^{48 *}$ & Phase II & $\begin{array}{l}\text { I. Docetaxel } 75 \mathrm{mg} / \mathrm{m}^{2} \mathrm{q} 3 \mathrm{wks}+ \\
\text { cisplatin } 75 \mathrm{mg} / \mathrm{m}^{2} \mathrm{q} 3 \mathrm{wks}+ \\
\text { wTrastuzumab } \\
\text { 2. Docetaxel } 75 \mathrm{mg} / \mathrm{m}^{2} \mathrm{q} 3 \mathrm{wks}+ \\
\text { carboplatin AUC6 + } \\
\text { wTrastuzumab }\end{array}$ & $\begin{array}{l}1.62 \\
2.62\end{array}$ & $\begin{array}{l}\text { HER2+ advanced and } \\
\text { metastatic BC* }\end{array}$ & $\begin{array}{l}\text { I. ORR } 79 \% \text { ( } 95 \% \\
\mathrm{Cl}=66 \%-89 \%) \text { mTTP } \\
9.9 \text { months ( } 95 \% \\
\mathrm{Cl}=8.3-13.1 \text { months) } \\
\text { 2. ORR } 58 \% \text { ( } 95 \% \\
\mathrm{Cl}=44 \%-70 \%) \text { mTTP } \\
\text { I2.7 months ( } 95 \% \\
\mathrm{Cl}=8.6-15.5 \text { months) }\end{array}$ \\
\hline Robert et $\mathrm{a}^{51}$ & Phase III & $\begin{array}{l}\text { Arm A: } 6 \text { cycles of } \\
\mathrm{T}\left(175 \mathrm{mg} / \mathrm{m}^{2}\right) \text { q } 3 \mathrm{wks}+ \\
\text { carboplatin AUC } 6 \text { q3wks + } \\
\text { wTrastuzumab } \\
\text { Arm B: } 6 \text { cycles of } \mathrm{T}\left(175 \mathrm{mg} / \mathrm{m}^{2}\right) \\
\text { q3wks + wTrastuzumab }\end{array}$ & 196 & $\begin{array}{l}\text { Previously untreated } \\
\text { HER2+ metastatic BC }\end{array}$ & $\begin{array}{l}\text { ORR Arm A 52\% } \\
(95 \% \mathrm{Cl}=42 \%-62 \%) \\
\text { ORR Arm B 36\% } \\
(95 \% \mathrm{Cl}=26 \%-46 \%) \\
(P=0.04) \\
\text { PFS Arm A } 10.7 \text { months } \\
\text { PFS Arm B } 7.1 \text { months } \\
\text { HR } 0.66 \\
(95 \% \mathrm{Cl}=0.59-0.73) \\
(P=0.03)\end{array}$ \\
\hline Montemurro et $\mathrm{al}^{58}$ & Phase II & $\begin{array}{l}\text { Docetaxel } 75 \mathrm{mg} / \mathrm{m}^{2} \mathrm{q} 3 \mathrm{wks}+ \\
\text { wTrastuzumab }\end{array}$ & 25 & $\begin{array}{l}\text { Heavily pretreated } \\
\text { HER2+ metastatic BC }\end{array}$ & ORR $70 \%$ \\
\hline Jahanzeb et al ${ }^{44}$ & Phase II & $\begin{array}{l}\text { Vinorelbine } 30 \mathrm{mg} / \mathrm{m}^{2} / \mathrm{w}+ \\
\text { wTrastuzumab }\end{array}$ & 40 & $\begin{array}{l}\text { Previously untreated } \\
\text { HER2+ metastatic BC }\end{array}$ & $\begin{array}{l}\text { ORR } 78 \% \\
(95 \% \mathrm{Cl}=62 \%-90 \%) \\
\text { mTTP I } 8 \text { months } \\
\text { (95\% Cl = } 13.7-34.2 \text { months) }\end{array}$ \\
\hline Burstein et $\mathrm{al}^{45}$ & Phase II & $\begin{array}{l}\text { Vinorelbine } 25 \mathrm{mg} / \mathrm{m}^{2} / \mathrm{w}+ \\
\text { wTrastuzumab }\end{array}$ & 54 & $\begin{array}{l}\text { Previously untreated } \\
\text { HER2+ metastatic BC }\end{array}$ & $\begin{array}{l}\text { ORR } 68 \% \\
(95 \% \mathrm{Cl}=54 \%-80 \%) \\
\text { mTTP } 5.6 \text { months } \\
(95 \% \mathrm{Cl}=0.46-16 \text { months })\end{array}$ \\
\hline Schaller et $\mathrm{al}^{52}$ & Phase II & $\begin{array}{l}\text { Capecitabine } 2500 \mathrm{mg} / \mathrm{m}^{2} \text { day } \\
\mathrm{I}-14 \mathrm{q} 2 \mathrm{I}+\text { wTrastuzumab }\end{array}$ & 27 & $\begin{array}{l}\text { Heavily pretreated } \\
\text { HER2+ metastatic BC }\end{array}$ & $\begin{array}{l}\text { ORR } 78 \% \\
\text { PFS } 6.7 \text { months }\end{array}$ \\
\hline
\end{tabular}


Table I (Continued)

\begin{tabular}{|c|c|c|c|c|c|}
\hline Author & Study & Drugs & No. of patients & $\begin{array}{l}\text { Patient's } \\
\text { characteristics }\end{array}$ & Main results \\
\hline O'Shaughnessy et al ${ }^{49}$ & Phase II & $\begin{array}{l}\text { Gemcitabine } 1200 \mathrm{mg} / \mathrm{m}^{2} \text { days } \\
\text { I,8 q2I + wTrastuzumab }\end{array}$ & 64 & HER2+ metastatic BC & $\begin{array}{l}\text { ORR } 38 \% \\
(95 \% \mathrm{Cl}=26 \%-50 \%) \\
\text { mTTP } 5.8 \text { months }\end{array}$ \\
\hline Pegram and Slamon ${ }^{42}$ & Phase I/II & Cisplatin + wTrastuzumab & 37 & HER2+ metastatic BC & $\begin{array}{l}\text { ORR } 24.3 \% \\
\text { mTTP } 8.4 \text { months }\end{array}$ \\
\hline Chia et $\mathrm{al}^{50}$ & Phase II & $\begin{array}{l}\text { PLD } 50 \mathrm{mg} / \mathrm{m}^{2} \mathrm{q} 4 \mathrm{wks}+ \\
\text { wTrastuzumab }\end{array}$ & 30 & $\begin{array}{l}\text { Previously untreated } \\
\text { HER2+ metastatic BC }\end{array}$ & $\begin{array}{l}\text { ORR } 38 \% \\
(95 \% \mathrm{Cl}=21.1 \%-78.9 \%) \\
\text { PFS I } 2 \text { months }\end{array}$ \\
\hline Andreopoulou et $\mathrm{a}^{53}$ & Phase II & $\begin{array}{l}\text { PLD } 50 \text { mg/m² q4wks + } \\
\text { wTrastuzumab }\end{array}$ & 12 & $\begin{array}{l}\text { Heavily pretreated } \\
\text { HER2+ metastatic BC }\end{array}$ & $\begin{array}{l}\text { The trial closed after } \\
2.5 \text { years for slow accrual }\end{array}$ \\
\hline Cortes et $\mathrm{al}^{54}$ & Phase II & $\begin{array}{l}\text { Nonpegylated LD } 50 \mathrm{mg} / \mathrm{m}^{2} \\
\text { q3wks + paclitaxel } 80 \mathrm{mg} / \mathrm{m}^{2} / \mathrm{w}+ \\
\text { wTrastuzumab }\end{array}$ & 69 & $\begin{array}{l}\text { Previously untreated } \\
\text { HER2+ metastatic BC }\end{array}$ & $\begin{array}{l}\text { ORR } 98.1 \%(95 \% \\
\mathrm{Cl}=90.1 \%-99.9 \%) \\
\text { mTTP } 22.1 \text { months } \\
\text { (95\% Cl= } 16.4-46.3 \text { months) }\end{array}$ \\
\hline Christodoulou et $\mathrm{al}^{55}$ & Phase II & $\begin{array}{l}\text { PLD } 30 \text { mg/m² q3wks + } \\
\text { q3wTrastuzumab }\end{array}$ & 37 & HER2+ metastatic BC & $\begin{array}{l}\text { ORR } 22 \% \\
\text { PFS } 6.5 \text { months } \\
(95 \% \mathrm{Cl}=0.8-31.1 \text { months })\end{array}$ \\
\hline Stickeler et $\mathrm{al}^{56}$ & Phase II & $\begin{array}{l}\text { PLD } 40 \mathrm{mg} / \mathrm{m}^{2} \mathrm{q} 4 \mathrm{wks}+ \\
\text { wTrastuzumab }\end{array}$ & 16 & $\begin{array}{l}\text { Previously untreated } \\
\text { HER2+ metastatic BC }\end{array}$ & $\begin{array}{l}\text { CBR } 50 \% \\
\text { PFS } 9.67 \text { months }\end{array}$ \\
\hline Venturini et $\mathrm{al}^{57}$ & Phase II & $\begin{array}{l}\text { Nonpegylated LD } 50 \mathrm{mg} / \mathrm{m}^{2} \\
\text { q3wks + docetaxel } 75 \mathrm{mg} / \mathrm{m}^{2} \\
\text { q3wks + wTrastuzumab }\end{array}$ & 31 & $\begin{array}{l}\text { Previously untreated } \\
\text { HER2+ metastatic BC }\end{array}$ & $\begin{array}{l}\text { ORR } 65.5 \% \\
\text { mTTP } 13 \text { months }\end{array}$ \\
\hline
\end{tabular}

Notes: *This study includes two phase II studies: (I) BCIRGIOI and (2) UCLA-ORN. In the UCLA-ORN study, patients were previously treated with taxanes. Abbreviations: wTrastuzumab, trastuzumab loading dose of $4 \mathrm{mg} / \mathrm{kg}$ followed by weekly doses of $2 \mathrm{mg} / \mathrm{kg}$; R, randomized; HER2+, HER2 positive; BC, breast cancer; chemo, chemotherapy; mTTP, median time to progression; OS, overall survival; q3wTrastuzumab, trastuzumab loading dose of $8 \mathrm{mg} / \mathrm{kg}$ followed by $6 \mathrm{mg} / \mathrm{kg}$ every 3 weeks; ORR, overall response rate (CR-complete remission + PR-partial remission); w, week; wks, weeks; D, doxorubicin; T, paclitaxel; AUC, area under curve; PFS, progression-free survival; PLD, pegylated liposomal doxorubicin; LD, liposomal doxorubicin; CBR, clinical benefit rate (CR + PR + stable disease-SD lasting 6 months or more).

Clinical practice shows that initial response to trastuzumab is almost invariably followed by tumor progression. ${ }^{59,73}$ Moreover, a large percentage of women fail to respond to trastuzumab, showing primary resistance..$^{10,74}$

At present, neither the mechanism of action nor the mechanisms of resistance to trastuzumab are completely understood. Nevertheless, several hypotheses have been proposed (Figure 2).

\section{HER2 downstream signaling adaptability}

HER2 plays a key role as positive regulator of a high complexity signaling network, consisting of distinct semiautonomous functional units that show strong internal connections, high adaptability, and very complex regulation.

This complexity and, at the same time, the flexibility and modularity of the signaling transduction pathway explain why the network can maintain proper function in the face of efficient inhibition of individual component, such as HER $2 .^{75}$

An increasing body of evidence sustains the central role of adaptive modulation of PI3K/Akt/mTor signaling pathway in resistance to anti-HER2-targeted agents.
Sergina et $\mathrm{al}^{76}$ have provided evidence that a chronic exposure to HER2 inhibitors may result in enhanced positive feedback mechanism controlled by Akt, whereby Akt inhibition leads to HER3 redistribution to the cell membrane and to sustained HER3 phosphorylation, resulting in cellular adaptation with the potential of reducing the efficacy of these drugs.

Nagata et $\mathrm{al}^{77}$ suggested an important role of decreased expression of the PTEN (phosphatase and tensin homolog) protein in development of resistance to trastuzumab. In preclinical models, they demonstrated that trastuzumab causes a disruption of the binding of Src to HER2, allowing PTEN to inhibit Akt therefore inducing growth arrest. When PTEN levels are low, however, Akt remains active and trastuzumab efficacy is impaired. A correlation between PTEN loss and resistance to trastuzumab was also shown in a retrospective analysis on HER2 positive BC patients.

Moreover, mutations in PI3KCA gene sequence can impair the ability of PTEN to inhibit Akt, also in presence of normal levels of PTEN, therefore contributing to trastuzumab resistance. ${ }^{78}$ 


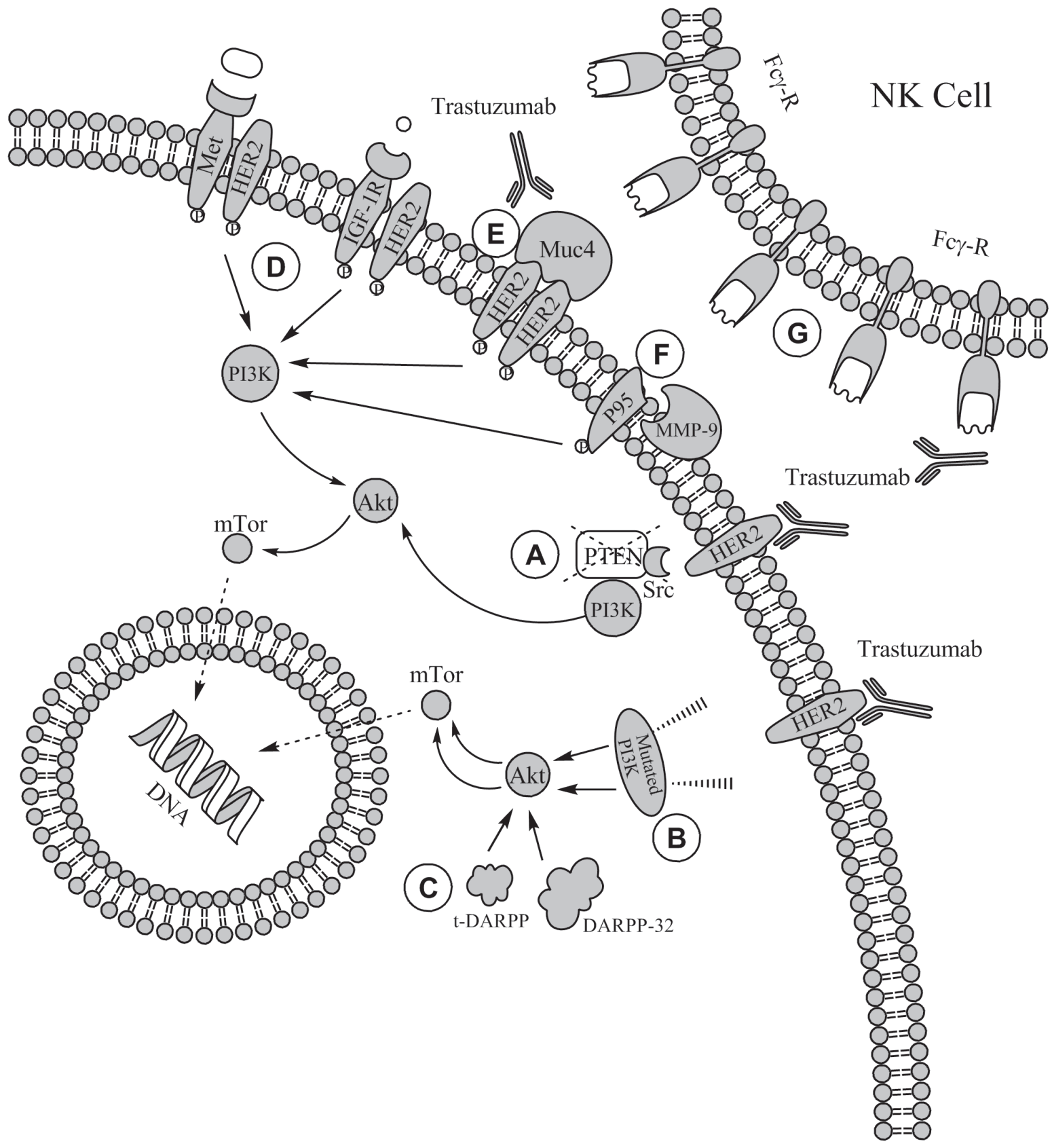

Figure 2 Mechanisms of resistance to trastuzumab. A) Loss of PTEN protein can impair efficacy of trastuzumab; B) mutation of PI3KCA gene sequence C) Overexpression of DARPP-32 and its truncated form t-DARPP, leading to increased phosphorylation of Akt; D) HER2 can dimerize with other tyrosine kinase receptors, such as Met or IGF$I R$, activating alternative signaling pathways; E) binding of HER2 with trastuzumab can be prevented by other cellular surface proteins, such as Muc4, F) or by the shedding of the extracellular domain of HER2 mediated by metalloproteinases; G) Fc $\gamma$-receptor polymorphisms can impair antibody-dependent cell-mediated cytotoxicity (ADCC) in vivo.

Abbreviations: HER2, human epidermal growth factor receptor 2; NK, natural killer; Fc $\gamma R$, fragment crystallizable region gamma receptor; Src, Rous sarcoma tyrosine kinase; PTEN, phosphatase and tensin homolog; PI3K, phosphatidylinositol 3-kinases; Akt, serine/threonine protein kinase; mTor, mammalian target of rapamycin; DARPP-32, dopamine- and cyclic-AMP-regulated phosphoprotein; t-DARPP, truncated form of dopamine- and cyclic-AMP-regulated phosphoprotein; MMP9, matrix metallopeptidase 9; P95, truncated form of HER2; Muc4, mucin 4; IGF-IR, insulin-like growth factor receptor I; Met, hepatocyte growth factor receptor.

More recently, Belkhiri et al ${ }^{79}$ described a possible mechanism of resistance involving both DARPP-32, a neuronally characterized protein that is centrally involved in dopamine-induced signaling pathways in the brain and is best known as a potent inhibitor of phosphatase I in neurosignaling and its truncated form, known as t-DARPP. Overexpression of both DARPP32 and t-DARPP led to increased phosphorylation of Akt and increased BCL2 protein levels in trastuzumab-resistant cell lines ${ }^{79}$ and in vivo. ${ }^{80}$ Moreover, t-DARPP contributes to trastuzumab resistance by blocking 
the antibody's effect on HER2 and maintaining its high levels in these cells via HSP90-mediated stabilization. ${ }^{79}$

Furthermore, a role in developing resistance to trastuzumab is probably played by dysregulation of mechanisms controlling survival and apoptosis. ${ }^{81}$ Recently, it has been shown that upregulation of survivin leads to the development of resistance to lapatinib, a dual inhibitor of EGFR and HER2. ${ }^{82,83}$

Moreover, although downregulation of survivin seems to be essential for trastuzumab-mediated induction of apoptosis, ${ }^{84}$ a failure in its downregulation could contribute to resistance. ${ }^{85}$

\section{Activation of alternative signaling pathways}

HER2 is the preferred dimerization partner of the other ErbB family receptors and acts as an 'amplifier' for the signal transduction coming outside the cell. ${ }^{75}$ However, the activation of downstream signaling components can also occur via the formation of complexes that do not contain HER2, such as EGFR homodimers or EGFR/HER3 heterodimers. ${ }^{5}$ Signaling through these alternate complexes might provide a mechanism for bypassing the requirement for HER2-mediated signaling and thereby circumvent HER2-targeted inhibitors. ${ }^{86}$ Moreover, overexpression of EGF family ligands, such as TGF- $\alpha$, EGF, heregulin, betacellulin, and others, can contribute to trastuzumab resistance. ${ }^{87-90}$

IGF-1R plays a role in resistance. It was shown that cells overexpressing both HER2 and IGF-1R are insensitive to trastuzumab inhibition..$^{91}$ Nahta et $\mathrm{al}^{92}$ demonstrated that IGF-1R can heterodimerize with HER2 and can induce its phosphorylation in trastuzumab-resistant cells, resulting in activation of a downstream cascade that involves phosphorylation of $\mathrm{PI} 3 \mathrm{~K} / \mathrm{Akt}$.

More recently, it was also shown that other tyrosine kinase receptors such as Met receptor (hepatocite growth factor receptor) can interact with HER2 and IGF-1R and can contribute to resistance through the activation of the PI3K/ Akt signaling cascade. Met receptor is overexpressed with HER2 in a subset of aggressive breast cancers ${ }^{93}$ and trastuzumab treatment induces upregulation of Met. ${ }^{94}$ Moreover, Shattuck et $\mathrm{al}^{94}$ have provided evidence that in trastuzumabresistant cell lines, Met receptor activation protects cells against trastuzumab inhibition; conversely, loss of Met function, either through RNA-interference-mediated depletion or small-molecule-mediated inhibition, restores sensitivity to the antibody.
The nuclear factor NF-kB, which is a downstream mediator of growth signaling, has been shown to be frequently overexpressed and deregulated in HER2-positive breast cancers. ${ }^{95,96}$ It has been shown by Cardoso et al that the proteasome inhibitor bortezomib, which specifically inhibits the activity of NF-kB, is able to synergize with trastuzumab in HER2-overexpressing breast cancer cell lines. ${ }^{97}$

\section{Inaccessibility of epitope to trastuzumab}

Trastuzumab exerts its effects by binding an epitope on the juxtamembrane extracellular domain (ECD) of HER2. ${ }^{98}$ Steric interference by extracellular molecules can prevent the binding of the antibody to its target and can therefore contribute to resistance.

Overexpression of MUC4, a membrane-associated sialomucin, was associated by Nagy et al ${ }^{99}$ with resistance to trastuzumab in a HER2-overexpressing cancer cell line (JIMT-1) established from a patient showing resistance to the antibody. The authors observed that the expression of MUC4 was higher in the resistant clone (JIMT-1) than in trastuzumab-sensitive lines, and its level was inversely correlated with the trastuzumab binding capacity of single cells. Knockdown of MUC4 expression by RNA interference increased the binding of trastuzumab.

Furthermore, overexpression of hyaluronan receptor CD44 and MUC1 (a membrane mucin) truncated forms were shown to have a similar role in trastuzumab-resistant cancer cells. ${ }^{100,101}$

On the basis of the observation that trastuzumab binds a HER2 epitope which is different from that employed by IHC methods, Bussolati et al ${ }^{102}$ retrospectively tested a biotinylated trastuzumab (BiotHER) in HER2-amplified (FISH positive) breast cancer specimens. Positivity to BiotHER seems to predict more accurately than IHC and FISH the efficacy of trastuzumab-based therapy. These results indicate that lack of accessibility of the epitope to trastuzumab may limit the activity of this antibody in vivo, although further validation is needed. ${ }^{103}$

The association between trastuzumab and HER2 can also be prevented by shedding the ECD of the receptor and producing a truncated form of protein named p95-ErbB2. This truncated form of protein has constitutive kinase activity, but cannot bind trastuzumab; furthermore, its overexpression contributes to resistance..$^{98,104}$

The major responsible factors for the proteolytic cleavage of HER 2 are metalloproteinases, ${ }^{105}$ and inhibition of their proteolytic activity can circumvent trastuzumab resistance. ${ }^{106}$

Moreover, monitoring serum HER2 levels is a fascinating and relatively cheap strategy to predict response to 
trastuzumab treatment. Although several studies have shown a potential utility of the approach, ${ }^{107-109}$ others have failed to demonstrate a clear correlation between serum ECD and response to trastuzumab. ${ }^{110}$

\section{Safety and tolerability}

Although the focus of our critical review is metastatic breast cancer, we will discuss also the available data on cardiac toxicity derived from adjuvant trials.

\section{Cardiac toxicity in metastatic breast cancer}

Cardiac toxicity was an unexpected finding during the clinical development of trastuzumab; therefore, early clinical trials in the metastatic setting did not perform baseline or prospective cardiac monitoring, and did not exclude patients with underlying cardiac disease. The first signal of trastuzumab-associated cardiotoxicity was seen in the pivotal phase III trial by Slamon et al, which randomized 469 patients with HER2-overexpressing breast cancer to standard chemotherapy (either an anthracycline-containing regimen or paclitaxel) alone or standard chemotherapy plus concurrent weekly trastuzumab. ${ }^{10}$ This led to the formation of an independent Cardiac Review and Evaluation Committee (CREC) to retrospectively review the cardiac toxicity data from seven phase II and III studies in 1219 patients who received trastuzumab as monotherapy or in combination with chemotherapy. ${ }^{111}$ The CREC defined cardiac dysfunction as cardiomyopathy characterized by a decrease in cardiac leftventricular ejection fraction (LVEF) that was either global or more severe in the septum, by symptoms or associated signs of congestive heart failure (CHF), or a by decline in LVEF of $\geq 5 \%$ (with symptoms) or $10 \%$ (no symptoms) with an absolute LVEF of $\leq 55 \%$.

In the phase III trial, data from the CREC analysis demonstrated an unacceptable rate of cardiac toxicity in the group receiving concurrent anthracycline and trastuzumab. ${ }^{10}$ Cardiotoxicity (both symptomatic and asymptomatic) was reported in $27 \%$ of patients who received trastuzumab plus adriamycin and cyclophosphamide (AC) compared with $8 \%$ who received $\mathrm{AC}$ without trastuzumab. In contrast, $13 \%$ of patients in the paclitaxel plus trastuzumab arm developed cardiotoxicity, while only $1 \%$ of patients receiving paclitaxel alone were affected. Among patients with cardiac toxicity, the incidence of New York Heart Association (NYHA) class III or IV CHF was highest among patients who had received an anthracycline-based chemotherapy with trastuzumab $(16 \%)$ when compared to patients who received an anthracycline-based regimen without trastuzumab (3\%), paclitaxel-based chemotherapy with trastuzumab (2\%), and paclitaxel only (1\%). Furthermore, the recovery of patients who developed cardiac dysfunction differed between the treatment groups. Of the 34 patients who developed cardiac dysfunction while receiving $\mathrm{AC}$ plus trastuzumab, 7 had persistent NYHA class III/IV symptoms after treatment for CHF, compared with none of the 10 patients in the paclitaxel and trastuzumab arm. ${ }^{40}$ Recently, an interesting randomized phase II trial in HER2-positive metastatic breast cancer demonstrated that the association of the less-cardiotoxic anthracycline epirubicin at a low dose $(60 \mathrm{mg} / \mathrm{sqm})$ with trastuzumab is able to induce a significant amount of durable responses (57\%) and low cardiac toxicity (only $1.7 \%$ of dose-limiting cardiac toxicity). ${ }^{112}$ Moreover, most of the trials associating liposomal anthracyclines with trastuzumab in metastatic disease revealed low incidence of symptomatic cardiac events. ${ }^{50,53-57}$

The CREC also reviewed a number of trastuzumab monotherapy trials and found a $3 \%-7 \%$ range of cardiac dysfunction. Patients enrolled in these trials were largely unselected and many of the patients who developed cardiac dysfunction had underlying cardiac disease or had received a cumulative anthracycline dose $>400 \mathrm{mg} / \mathrm{m} \cdot{ }^{2,33,40,113}$ Guarneri et al evaluated the cardiac safety of long-term trastuzumab therapy in patients with advanced disease at a single institution. Cardiac events in this study were defined as an asymptomatic decrease of LVEF $<50 \%$, an absolute 20\% LVEF drop from baseline, or signs or symptoms of heart failure. Of 173 evaluable patients who received $\geq 1$ year of trastuzumab-based therapy (median length of treatment was 21.3 months), 49 patients (28\%) experienced a cardiac event, 19 of whom (10.9\%) suffered grade 3 cardiac toxicity. All but 3 of these patients had improvement in LVEF and/or symptoms with the discontinuation of trastuzumab and activation of appropriate medical therapy. ${ }^{114}$

\section{Cardiac toxicity in the adjuvant setting}

The studies with trastuzumab in the adjuvant setting were designed considering, among other factors, the modest cardiotoxicity of this compound. The cardiac exclusion criteria were very strict in some trials and took into account the fact that no information of the long-term cardiac safety of trastuzumab was available at the time of study planning. In all studies, the baseline LVEF measured either by ultrasonography or multiple-gated acquisition scan (MUGA) had to be above the institutional lower normal limit, which 
is usually $50 \%-55 \%$. Furthermore, LVEF was monitored at regular intervals during treatment (every 3 months in most of the trials) in asymptomatic patients. Symptomatic cardiac toxicity occurred at acceptably low rates in all trials. It was slightly more frequent in trials where trastuzumab was administered concomitantly with taxanes, after exposure to anthracyclines, and less frequent in trials adopting the 'sequential' strategy. A relevant finding is that, in the two North American trials ${ }^{115}$ considering patients with symptomatic cardiotoxicity, those unable to start trastuzumab because of LVEF drop after AC and those developing asymptomatic cardiac toxicity, a total of $20 \%$ of patients did not receive the planned treatment with trastuzumab. This is much higher than what registered in the HERA trial, ${ }^{116}$ where only $5.2 \%$ of the patients discontinued trastuzumab because of cardiac toxicity.

The cardiac safety data of the BCIRG 006 study confirmed that the omission of anthracyclines resulted in reduced cardiac toxicity in the TCH arm. ${ }^{117}$

Cardiac safety results in the FinHER suggested that a short-term treatment with trastuzumab before anthracycline exposure might minimize the incidence of symptomatic CHF, which occurred in $0.9 \%$ and $1.7 \%$ of patients receiving chemotherapy alone or with trastuzumab, respectively. ${ }^{118}$

The cardiac safety findings of the randomized trials have several practical implications that merit being addressed. The cumulative incidence of cardiac events increased gradually during the scheduled trastuzumab treatment period. ${ }^{119-121}$ However, it remained approximately constant during follow-up after the completion of treatment. Therefore, although regular cardiac monitoring, (every 3 months), by LVEF assessment is generally advised in patients on treatment, its role during patient follow-up needs to be defined.

Another important issue to be addressed is whether the apparently low rates of cardiac events, either symptomatic or asymptomatic, are reproducible in the clinical practice. For example, some reports in patients receiving sequential trastuzumab, including our own, describe an incidence of trastuzumab discontinuation because of either overt cardiotoxicity or of asymptomatic LVEF drops outside clinical trials that is higher than that reported in the HERA trial. ${ }^{122,123}$ Although clinical cardiotoxicity occurs at a rate that is clinically acceptable, as many as $12 \%-18 \%$ of the patients may need trastuzumab discontinuation even if the sequential strategy is employed. The application of algorithms of trastuzumab discontinuation or prosecution in asymptomatic patients with LFEV drop ${ }^{124}$ and the establishment of trastuzumab-based regimens that minimize the risk of cardiac toxicity are two possible areas of intervention. One example is the TCH regimen used in the BCIRG 006 study, which several healthcare systems have approved for use in patients with contraindications to anthracyclines.

Despite having been reported as reversible by trastuzumab discontinuation and prompt administration of cardiac medications, trastuzumab-related cardiac toxicity may not recover in a significant proportion of patients. ${ }^{125}$ Obviously, this calls for the involvement of the cardiologist in the management of patients who are candidates to trastuzumab to evaluate their cardiac risk profile. At the same time, markers that could help predict patients more likely to develop reversible or irreversible cardiotoxicity are eagerly awaited. Recently, for example, an elevation of troponin I during trastuzumab has been shown to correlate with irreversible trastuzumab-related cardiac toxicity. ${ }^{126}$

The early use of beta-blockers and angiotensin-converting enzyme (ACE) inhibitors to prevent trastuzumab-related cardiotoxicity is another promising approach. ${ }^{127}$ These drugs can act on myocardial remodeling and have a well-established role in patients with trastuzumab-related cardiac toxicity. Preliminary results of a prospective trial have been recently reported by Munoz et al at the 2010 ASCO meeting. ${ }^{128}$ The use of beta-blockers and ACE inhibitors concomitantly with trastuzumab was associated with a smaller decrease in mean LVEF (4.7 versus 10.3 percentage points $P<0.001$ ) when compared to untreated patients.

Interestingly, smaller studies in the neoadjuvant setting have shown that the concurrent administration of conventional anthracyclines is associated with a low incidence of cardiac events. ${ }^{129,130}$ At the present time, it is impossible to ascertain whether these low rates of cardiac toxicity are due to the particular clinical setting or just due to accurate selection of patients. Therefore, outside clinical trials, the concomitant administration of trastuzumab and anthracyclines should be avoided.

\section{Conclusions, place in therapy}

Trastuzumab has improved survival of HER2-positive advanced breast cancer patients. On the basis of phase II and III trials, trastuzumab in association with chemotherapy is the standard treatment for HER2-overexpressing metastatic breast cancers. However, the optimal chemotherapeutic 
companion for trastuzumab is not defined. Probably, the best evidence-based combination is with a taxane (docetaxel or paclitaxel).

Although it is difficult to define an optimal strategy for second-line treatment of HER2-positive breast cancers, the most reasonable approach is the all-oral combination capecitabine-lapatinib. Continuation of trastuzumab beyond disease progression is sustained only by a few retrospective trials ${ }^{60,131-134}$ and the weak and biased randomized phase III trial by von Minckwitz et al, ${ }^{61}$ which compared capecitabine with capecitabine and trastuzumab after failure of a trastuzumab-containing frontline treatment. The only concern about trastuzumab treatment in metastatic disease is cardiac toxicity. However, clinical trials clearly indicate that, if the antibody is not used in association with anthracyclines, the rate of cardiac events is low and most of them are reversible. Moreover, not only associations with taxanes, vinorelbine, gemcitabine, capecitabine are safe and active but also with liposomal anthracyclines. However, in the absence of randomized phase III trials, the last category of drugs cannot be currently recommended in association with trastuzumab.

\section{Future perspectives: novel drugs under investigation}

At the moment, a number of novel anti-HER2-targeted agents are under evaluation. Because a comprehensive discussion of all these agents is beyond the scope of the review, in the following section, only the most promising drugs will be briefly considered.

Neratinib (HKI-272), an orally administered small molecule that acts as an irreversible inhibitor of the tyrosine kinase domain of EGFR, HER2, and HER4 (pan-HER inhibitor), ${ }^{135}$ showed impressive results in a multinational, multicenter, open-label, phase II trial conducted by Burstein et al, on locally advanced or metastatic breast cancer patients. ${ }^{136}$ Patients enrolled were included in two cohorts according to whether or not they had been previously exposed to trastuzumab. Patients in the latter cohort had to have progressed after at least 6 weeks of trastuzumab given in the metastatic or locally advanced setting, or during or after adjuvant trastuzumab. Treatment with neratinib yielded a response rate of $26 \%$ in trastuzumab-treated patients and 55\% in trastuzumab-naive patients. About $59 \%$ and $78 \%$ of trastuzumab exposed and unexposed patients, respectively, were alive and free from disease progression at 16 weeks from study entry (primary end point). Due to these impressive activity data, neratinib is now being actively investigated in combination with cytostatic agents such as paclitaxel, vinorelbine, and capecitabine. ${ }^{137-139}$

Pertuzumab is a fully humanized monoclonal antibody based on the human $\operatorname{IgG1}(\kappa)$ framework sequences, directed against the ECD of HER2. ${ }^{140}$ Pertuzumab differs from trastuzumab in the epitope binding regions of the light chain (12 amino acid differences). ${ }^{141}$ Upon epitope binding, pertuzumab neutralizes the ability of HER2 to dimerize with other HER2 molecules or with other members of the EGFR family.

As single agent, pertuzumab showed disappointing activity in a phase II study. ${ }^{142}$ Baselga et al conducted a phase II study with trastuzumab and pertuzumab in HER2-positive advanced breast cancer. ${ }^{143}$ Patients were eligible if they had received $\leq 3$ chemotherapy regimens and had developed progression during trastuzumab-based therapy. In 66 enrolled patients, the authors reported a response rate, clinical benefit rate (CBR), and median PFS of $24.4 \%, 50 \%$, and 5.5 months, respectively.

Trastuzumab-DM1 is a conjugated antibody that uses trastuzumab to deliver the maytansinoid agent DM1 to HER2positive cells. ${ }^{144}$ Once internalized, DM1 is released and binds to tubulin, thereby disrupting microtubule assembly/ disassembly dynamics and inhibiting cell division and proliferation of cancer cells that overexpress HER2. ${ }^{144}$ In a phase I study in trastuzumab-refractory, HER2-positive advanced breast cancer patients, this agent showed a favorable profile of toxicity at the dose of $3.6 \mathrm{mg} / \mathrm{kg}$ administered intravenously every 3 weeks. ${ }^{145}$ The authors also reported a response rate and CBR of $21 \%$ and $73 \%$, respectively, which make this agent a promising therapeutic opportunity.

Similarly, a phase Ib/II study associating trastuzumabDM1 and pertuzumab in patients with trastuzumab resistant, HER2-positive advanced breast cancer was presented at the 2010 ASCO meeting. ${ }^{146}$ The study included a dose-escalation phase followed by an expansion phase consisting of a formal phase II study in 60 patients. The expansion phase showed that, in the subset of patients with relapsed stage IV disease who could be evaluated for tumor response, this combination yielded a $35.7 \%$ ORR, which is an encouraging achievement. More recently, at ESMO 2010 a randomized phase III trial showed that trastuzumab DM1 has similar activity and a significantly lower toxicity in comparison with the association docetaxel and trastuzumab as frontline treatment of HER2 positive metastatic breast cancers. ${ }^{147}$

In conclusion, the treatment of HER2-positive metastatic breast cancer is in continuous evolution, and many different targeted therapies are in advanced stages of 
development. The future challenge for oncologists will be to optimally integrate all the available treatments to improve the outcome of HER2-positive metastatic breast cancers.

\section{Financial and competing interests disclosure}

All the authors of this article do not have relevant affiliations or financial involvement with any organization or entity with a financial interest in or financial conflict with the subject matter or materials discussed in the manuscript apart from those disclosed.

No writing assistance was utilized in the production of this manuscript.

\section{References}

1. Broekx S, Hond ED, Torfs R, et al. The costs of breast cancer prior to and following diagnosis. Eur J Health Econ. Epub 2010 Mar 20.

2. Katanoda K, Yako-Suketomo H. Comparison of time trends in breast cancer mortality (1990-2006) in the world, from the WHO mortality database [abstract]. Jpn J Clin Oncol. 2010;40:182.

3. Slamon DJ, Clark GM, Wong SG, Levin WJ, Ullrich A, McGuire WL. Human breast cancer: correlation of relapse and survival with amplification of the HER-2/neu oncogene. Science. 1987;235: $177-182$.

4. Slamon DJ, Godolphin W, Jones LA, et al. Studies of the HER-2/neu proto-oncogene in human breast and ovarian cancer. Science. 1989; 244:707-712.

5. Harari D, Yarden Y. Molecular mechanisms underlying ErbB2/HER2 action in breast cancer. Oncogene. 2000;19:6102-6114.

6. Owens M, Horten B, Da Silva M. HER2 Amplification ratios by fluorescence in situ hybridization and correlation with immunohistochemistry in a cohort of 6556 breast cancer tissues. Clin Breast Cancer. 2004;5:63-69.

7. Bender LM, Nahta R. Her2 cross talk and therapeutic resistance in breast cancer. Front Biosci. 2008;13:3906-3912.

8. Yarden Y, Sliwkowski MX. Untangling the ErbB signalling network. Nat Rev Mol Cell Biol. 2001;2:127-137.

9. Valabrega G, Montemurro F, Aglietta M. Trastuzumab: mechanism of action, resistance and future perspectives in HER2-overexpressing breast cancer. Ann Oncol. 2007;18:977-984.

10. Slamon DJ, Leyland-Jones B, Shak S, et al. Use of chemotherapy plus a monoclonal antibody against HER2 for metastatic breast cancer that overexpresses HER2. N Engl J Med. 2001;344:783-792.

11. Sauter G, Lee J, Bartlett JM, Slamon DJ, Press MF. Guidelines for human epidermal growth factor receptor 2 testing: biologic and methodologic considerations. J Clin Oncol. 2009;27:1323-1333.

12. Gancberg D, Jarvinen T, di LA, et al. Evaluation of HER-2/NEU protein expression in breast cancer by immunohistochemistry: an interlaboratory study assessing the reproducibility of HER-2/NEU testing. Breast Cancer Res Treat. 2002;74:113-120.

13. Press MF, Sauter G, Bernstein L, et al. Diagnostic evaluation of HER-2 as a molecular target: an assessment of accuracy and reproducibility of laboratory testing in large, prospective, randomized clinical trials. Clin Cancer Res. 2005;11:6598-6607.

14. Middleton LP, Price KM, Puig P, et al. Implementation of American Society of Clinical Oncology/College of American Pathologists HER2 Guideline Recommendations in a tertiary care facility increases HER2 immunohistochemistry and fluorescence in situ hybridization concordance and decreases the number of inconclusive cases. Arch Pathol Lab Med. 2009;133:775-780.
15. Coussens L, Yang-Feng TL, Liao YC, et al. Tyrosine kinase receptor with extensive homology to EGF receptor shares chromosomal location with neu oncogene. Science. 1985;230:1132-1139.

16. Clynes RA, Towers TL, Presta LG, Ravetch JV. Inhibitory Fc receptors modulate in vivo cytoxicity against tumor targets. Nat Med. 2000;6:443-446.

17. Gennari R, Menard S, Fagnoni F, et al. Pilot study of the mechanism of action of preoperative trastuzumab in patients with primary operable breast tumors overexpressing HER2. Clin Cancer Res. 2004;10: $5650-5655$.

18. Repka T, Chiorean EG, Gay J, et al. Trastuzumab and interleukin-2 in HER2-positive metastatic breast cancer: a pilot study. Clin Cancer Res. 2003;9:2440-2446.

19. Musolino A, Naldi N, Bortesi B, et al. Immunoglobulin G fragment $\mathrm{C}$ receptor polymorphisms and clinical efficacy of trastuzumab-based therapy in patients with HER-2/neu-positive metastatic breast cancer. J Clin Oncol. 2008;26:1789-1796.

20. Tamura K, Shimizu C, Koizumi F, et al. Correlation of Fc $\{$ gamma $\}$ R IIa-H131R and IIIa-V158F polymorphisms and clinical outcome of trastuzumab in both neoadjuvant and metastatic setting in patients with HER-2 positive breast cancer [abstract]. J Clin Oncol (Meeting Abstracts). 2009;27:1100.

21. Bibeau F, Lopez-Crapez E, Di FF, et al. Impact of Fc $\{$ gamma $\}$ RIIaFc $\{$ gamma $\}$ RIIIa polymorphisms and KRAS mutations on the clinical outcome of patients with metastatic colorectal cancer treated with cetuximab plus irinotecan. J Clin Oncol. 2009;27:1122-1129.

22. Lopez-Albaitero A, Lee SC, Morgan S, et al. Role of polymorphic Fc gamma receptor IIIa and EGFR expression level in cetuximab mediated, NK cell dependent in vitro cytotoxicity of head and neck squamous cell carcinoma cells. Cancer Immunol Immunother. 2009;58:1853-1864.

23. Beano A, Signorino E, Evangelista A, et al. Correlation between NK function and response to trastuzumab in metastatic breast cancer patients. J Transl Med. 2008;6:25.

24. Varchetta S, Gibelli N, Oliviero B, et al. Elements related to heterogeneity of antibody-dependent cell cytotoxicity in patients under trastuzumab therapy for primary operable breast cancer overexpressing Her2. Cancer Res. 2007;67:11991-11999.

25. Mozaffari F, Lindemalm C, Choudhury A, et al. NK-cell and T-cell functions in patients with breast cancer: effects of surgery and adjuvant chemo- and radiotherapy. Br J Cancer. 2007;97:105-111.

26. Lewis GD, Figari I, Fendly B, et al. Differential responses of human tumor cell lines to anti-p185HER2 monoclonal antibodies. Cancer Immunol Immunother. 1993;37:255-263.

27. Le XF, Claret FX, Lammayot A, et al. The role of cyclin-dependent kinase inhibitor p27Kip1 in anti-HER2 antibody-induced G1 cell cycle arrest and tumor growth inhibition. J Biol Chem. 2003;278:23441-23450.

28. Hudziak RM, Lewis GD, Winget M, Fendly BM, Shepard HM, Ullrich A. p185HER2 monoclonal antibody has antiproliferative effects in vitro and sensitizes human breast tumor cells to tumor necrosis factor. Mol Cell Biol. 1989;9:1165-1172.

29. Bruno R, Washington CB, Lu JF, Lieberman G, Banken L, Klein P. Population pharmacokinetics of trastuzumab in patients with HER2+ metastatic breast cancer. Cancer Chemother Pharmacol. 2005;56:361-369.

30. Baselga J, Tripathy D, Mendelsohn J, et al. Phase II study of weekly intravenous recombinant humanized anti-p185HER2 monoclonal antibody in patients with HER2/neu-overexpressing metastatic breast cancer. J Clin Oncol. 1996;14:737-744.

31. Baselga J, Carbonell X, Castaneda-Soto NJ, et al. Phase II study of efficacy, safety, and pharmacokinetics of trastuzumab monotherapy administered on a 3-weekly schedule. J Clin Oncol. 2005;23:2162-2171.

32. Ghahramani P, Barton C, Leyland-Jones B. Pharmacokinetics of herceptin administered three-weekly compared to weekly: a simulation based on data from the clinical studies [abstract]. The Breast. 2003;12:S40.

33. Vogel CL, Cobleigh MA, Tripathy D, et al. Efficacy and safety of trastuzumab as a single agent in first-line treatment of HER2-overexpressing metastatic breast cancer. J Clin Oncol. 2002;20:719-726. 
34. Holliger P, Hudson PJ. Engineered antibody fragments and the rise of single domains. Nat Biotechnol. 2005;23:1126-1136.

35. Baker JH, Lindquist KE, Huxham LA, Kyle AH, Sy JT, Minchinton AI. Direct visualization of heterogeneous extravascular distribution of trastuzumab in human epidermal growth factor receptor type 2 overexpressing xenografts. Clin Cancer Res. 2008;14:2171-2179.

36. Jain RK, Baxter LT. Mechanisms of heterogeneous distribution of monoclonal antibodies and other macromolecules in tumors: significance of elevated interstitial pressure. Cancer Res. 1988;48: 7022-7032.

37. Jain RK. Physiological barriers to delivery of monoclonal antibodies and other macromolecules in tumors. Cancer Res. 1990;50: $814 \mathrm{~s}-819 \mathrm{~s}$.

38. Park IH, Ro J, Lee KS, Nam BH, Kwon Y, Shin KH. Trastuzumab treatment beyond brain progression in HER2-positive metastatic breast cancer. Ann Oncol. 2009;20:56-62.

39. Stemmler HJ, Schmitt M, Willems A, Bernhard H, Harbeck N, Heinemann V. Ratio of trastuzumab levels in serum and cerebrospinal fluid is altered in HER2-positive breast cancer patients with brain metastases and impairment of blood-brain barrier. Anticancer Drugs. 2007; 18:23-28.

40. Cobleigh MA, Vogel CL, Tripathy D, et al. Multinational study of the efficacy and safety of humanized anti-HER2 monoclonal antibody in women who have HER2-overexpressing metastatic breast cancer that has progressed after chemotherapy for metastatic disease. J Clin Oncol. 1999;17:2639-2648.

41. Marty M, Cognetti F, Maraninchi D, et al. Randomized phase II trial of the efficacy and safety of trastuzumab combined with docetaxel in patients with human epidermal growth factor receptor 2-positive metastatic breast cancer administered as first-line treatment: the M77001 study group. J Clin Oncol. 2005;23:4265-4274.

42. Pegram MD, Slamon DJ. Combination therapy with trastuzumab (Herceptin) and cisplatin for chemoresistant metastatic breast cancer: evidence for receptor-enhanced chemosensitivity. Semin Oncol. 1999;26:89-95.

43. Esteva FJ, Valero V, Booser D, et al. Phase II study of weekly docetaxel and trastuzumab for patients with HER-2-overexpressing metastatic breast cancer. J Clin Oncol. 2002;20:1800-1808.

44. Jahanzeb M, Mortimer JE, Yunus F, et al. Phase II trial of weekly vinorelbine and trastuzumab as first-line therapy in patients with HER2(+) metastatic breast cancer. Oncologist. 2002;7:410-417.

45. Burstein HJ, Harris LN, Marcom PK, et al. Trastuzumab and vinorelbine as first-line therapy for HER2-overexpressing metastatic breast cancer: multicenter phase II trial with clinical outcomes, analysis of serum tumor markers as predictive factors, and cardiac surveillance algorithm. J Clin Oncol. 2003;21:2889-2895.

46. Sledge GW Jr. Gemcitabine, paclitaxel, and trastuzumab in metastatic breast cancer. Oncology (Williston Park). 2003;17:33-35.

47. Bianchi G, Albanell J, Eiermann W, et al. Pilot trial of trastuzumab starting with or after the doxorubicin component of a doxorubicin plus paclitaxel regimen for women with HER2-positive advanced breast cancer. Clin Cancer Res. 2003;9:5944-5951.

48. Pegram MD, Pienkowski T, Northfelt DW, et al. Results of two openlabel, multicenter phase II studies of docetaxel, platinum salts, and trastuzumab in HER2-positive advanced breast cancer. J Natl Cancer Inst. 2004;96:759-769.

49. O’Shaughnessy JA, Vukelja S, Marsland T, Kimmel G, Ratnam S, Pippen JE. Phase II study of trastuzumab plus gemcitabine in chemotherapy-pretreated patients with metastatic breast cancer. Clin Breast Cancer. 2004;5:142-147.

50. Chia S, Clemons M, Martin LA, et al. Pegylated liposomal doxorubicin and trastuzumab in HER-2 overexpressing metastatic breast cancer: a multicenter phase II trial. J Clin Oncol. 2006;24:2773-2778.

51. Robert N, Leyland-Jones B, Asmar L, et al. Randomized phase III study of trastuzumab, paclitaxel, and carboplatin compared with trastuzumab and paclitaxel in women with HER-2-overexpressing metastatic breast cancer. J Clin Oncol. 2006;24:2786-2792.
52. Schaller G, Fuchs I, Gonsch T, et al. Phase II study of capecitabine plus trastuzumab in human epidermal growth factor receptor 2 overexpressing metastatic breast cancer pretreated with anthracyclines or taxanes. J Clin Oncol. 2007;25:3246-3250.

53. Andreopoulou E, Gaiotti D, Kim E, et al. Feasibility and cardiac safety of pegylated liposomal doxorubicin plus trastuzumab in heavily pretreated patients with recurrent HER2-overexpressing metastatic breast cancer. Clin Breast Cancer. 2007;7:690-696.

54. Cortes J, Di CS, Climent MA, et al. Nonpegylated liposomal doxorubicin (TLC-D99), paclitaxel, and trastuzumab in HER-2-overexpressing breast cancer: a multicenter phase I/II study. Clin Cancer Res. 2009; 15:307-314.

55. Christodoulou C, Kostopoulos I, Kalofonos HP, et al. Trastuzumab combined with pegylated liposomal doxorubicin in patients with metastatic breast cancer. Phase II Study of the Hellenic Cooperative Oncology Group (HeCOG) with biomarker evaluation. Oncology. 2009;76: 275-285.

56. Stickeler E, Klar M, Watermann D, et al. Pegylated liposomal doxorubicin and trastuzumab as 1 st and 2nd line therapy in her2/neu positive metastatic breast cancer: a multicenter phase II trial. Breast Cancer Res Treat. 2009;117:591-598.

57. Venturini M, Bighin C, Puglisi F, et al. A multicentre Phase II study of non-pegylated liposomal doxorubicin in combination with trastuzumab and docetaxel as first-line therapy in metastatic breast cancer. Breast. 2010;19(5):333-338.

58. Montemurro F, Choa G, Faggiuolo R, et al. Safety and activity of docetaxel and trastuzumab in HER2 overexpressing metastatic breast cancer: a pilot phase II study. Am J Clin Oncol. 2003;26: 95-97.

59. Montemurro F, Redana S, Viale G, et al. Retrospective evaluation of clinical outcomes in patients with HER2-positive advanced breast cancer progressing on trastuzumab-based therapy in the pre-lapatinib era. Clin Breast Cancer. 2008;8:436-442.

60. Gelmon KA, Mackey J, Verma S, et al. Use of trastuzumab beyond disease progression: observations from a retrospective review of case histories. Clin Breast Cancer. 2004;5:52-58.

61. von MG, du BA, Schmidt M, et al. Trastuzumab beyond progression in human epidermal growth factor receptor 2-positive advanced breast cancer: a german breast group 26/breast international group 03-05 study. J Clin Oncol. 2009;27:1999-2006.

62. Geyer CE, Forster J, Lindquist D, et al. Lapatinib plus capecitabine for HER2-positive advanced breast cancer. $N$ Engl J Med. 2006;355: 2733-2743.

63. Lin NU, Dieras V, Paul D, et al. Multicenter phase II study of lapatinib in patients with brain metastases from HER2-positive breast cancer. Clin Cancer Res. 2009;15:1452-1459.

64. Blackwell KL, Burstein HJ, Storniolo AM, et al. Randomized study of Lapatinib alone or in combination with trastuzumab in women with ErbB2-positive, trastuzumab-refractory metastatic breast cancer. J Clin Oncol. 2010;28:1124-1130.

65. Dowsett M, Allred C, Knox J, et al. Relationship between quantitative estrogen and progesterone receptor expression and human epidermal growth factor receptor 2 (HER-2) status with recurrence in the Arimidex, Tamoxifen, Alone or in Combination trial. J Clin Oncol. 2008;26:1059-1065.

66. Rasmussen BB, Regan MM, Lykkesfeldt AE, et al. Adjuvant letrozole versus tamoxifen according to centrally-assessed ERBB2 status for postmenopausal women with endocrine-responsive early breast cancer: supplementary results from the BIG 1-98 randomised trial. Lancet Oncol. 2008;9:23-28.

67. Dowsett M, Harper-Wynne C, Boeddinghaus I, et al. HER-2 amplification impedes the antiproliferative effects of hormone therapy in estrogen receptor-positive primary breast cancer. Cancer Res. 2001;61: 8452-8458.

68. Arpino G, Weiss H, Lee AV, et al. Estrogen receptor-positive, progesterone receptor-negative breast cancer: association with growth factor receptor expression and tamoxifen resistance. J Natl Cancer Inst. 2005; 97:1254-1261. 
69. Kaufman B, Mackey JR, Clemens MR, et al. Trastuzumab plus anastrozole versus anastrozole alone for the treatment of postmenopausal women with human epidermal growth factor receptor 2-positive, hormone receptor-positive metastatic breast cancer: results from the randomized phase III TAnDEM study. J Clin Oncol. 2009;27: 5529-5537.

70. Johnston S, Pippen J Jr, Pivot X, et al. Lapatinib combined with letrozole versus letrozole and placebo as first-line therapy for postmenopausal hormone receptor-positive metastatic breast cancer. J Clin Oncol. 2009;27:5538-5546.

71. Schwartzberg LS, Franco SX, Florance A, O’Rourke L, Maltzman J, Johnston S. Lapatinib plus letrozole as first-line therapy for HER-2+ hormone receptor-positive metastatic breast cancer. Oncologist. 2010;15:122-129.

72. Spector NL, Blackwell KL. Understanding the mechanisms behind trastuzumab therapy for human epidermal growth factor receptor 2-positive breast cancer. J Clin Oncol. 2009;27:5838-5847.

73. Stemmler HJ, Kahlert S, Siekiera W, Untch M, Heinrich B, Heinemann V. Prolonged survival of patients receiving trastuzumab beyond disease progression for HER2 overexpressing metastatic breast cancer (MBC). Onkologie. 2005;28:582-586.

74. Nahta R, Esteva FJ. Trastuzumab: triumphs and tribulations. Oncogene. 2007;26:3637-3643.

75. Citri A, Yarden Y. EGF-ERBB signalling: towards the systems level Nat Rev Mol Cell Biol. 2006;7:505-516.

76. Sergina NV, Rausch M, Wang D, et al. Escape from HER-family tyrosine kinase inhibitor therapy by the kinase-inactive HER3. Nature. 2007;445:437-441.

77. Nagata Y, Lan KH, Zhou X, et al. PTEN activation contributes to tumor inhibition by trastuzumab, and loss of PTEN predicts trastuzumab resistance in patients. Cancer Cell. 2004;6:117-127.

78. Berns K, Horlings HM, Hennessy BT, et al. A functional genetic approach identifies the PI3K pathway as a major determinant of trastuzumab resistance in breast cancer. Cancer Cell. 2007;12:395-402.

79. Belkhiri A, Dar AA, Peng DF, et al. Expression of t-DARPP mediates trastuzumab resistance in breast cancer cells. Clin Cancer Res. 2008; $14: 4564-4571$

80. Hamel S, Bouchard A, Ferrario C, et al. Both t-Darpp and DARPP-32 can cause resistance to trastuzumab in breast cancer cells and are frequently expressed in primary breast cancers. Breast Cancer Res Treat 2010;120:47-57.

81. Chen FL, Xia W, Spector NL. Acquired resistance to small molecule ErbB2 tyrosine kinase inhibitors. Clin Cancer Res. 2008;14:6730-6734.

82. Xia W, Bacus S, Hegde P, et al. A model of acquired autoresistance to a potent ErbB2 tyrosine kinase inhibitor and a therapeutic strategy to prevent its onset in breast cancer. Proc Natl Acad Sci USA. 2006;103: 7795-7800.

83. Xia W, Bisi J, Strum J, et al. Regulation of survivin by ErbB2 signaling: therapeutic implications for ErbB2-overexpressing breast cancers Cancer Res. 2006;66:1640-1647.

84. Asanuma H, Torigoe T, Kamiguchi K, et al. Survivin expression is regulated by coexpression of human epidermal growth factor receptor 2 and epidermal growth factor receptor via phosphatidylinositol 3-kinase/AKT signaling pathway in breast cancer cells. Cancer Res. 2005;65:11018-11025.

85. Ozbay T, Durden DL, Liu T, O’Regan RM, Nahta R. In vitro evaluation of pan-PI3-kinase inhibitor SF1126 in trastuzumab-sensitive and trastuzumab-resistant HER2-over-expressing breast cancer cells. Cancer Chemother Pharmacol. 2010;65:697-706.

86. Nahta R, Yu D, Hung MC, Hortobagyi GN, Esteva FJ. Mechanisms of disease: understanding resistance to HER2-targeted therapy in human breast cancer. Nat Clin Pract Oncol. 2006;3: 269-280.

87. Motoyama AB, Hynes NE, Lane HA. The efficacy of ErbB receptortargeted anticancer therapeutics is influenced by the availability of epidermal growth factor-related peptides. Cancer Res. 2002;62: 3151-3158.
88. Diermeier S, Horvath G, Knuechel-Clarke R, Hofstaedter F, Szollosi J, Brockhoff G. Epidermal growth factor receptor coexpression modulates susceptibility to Herceptin in HER2/neu overexpressing breast cancer cells via specific erbB-receptor interaction and activation. Exp Cell Res. 2005;304:604-619.

89. Valabrega G, Montemurro F, Sarotto I, et al. TGFalpha expression impairs Trastuzumab-induced HER2 downregulation. Oncogene. 2005;24:3002-3010.

90. Ritter CA, Perez-Torres M, Rinehart C, et al. Human breast cancer cells selected for resistance to trastuzumab in vivo overexpress epidermal growth factor receptor and ErbB ligands and remain dependent on the ErbB receptor network. Clin Cancer Res. 2007;13: 4909-4919.

91. Lu Y, Zi X, Zhao Y, Mascarenhas D, Pollak M. Insulin-like growth factor-I receptor signaling and resistance to trastuzumab (Herceptin) J Natl Cancer Inst. 2001;93:1852-1857.

92. Nahta R, Yuan LX, Zhang B, Kobayashi R, Esteva FJ. Insulin-like growth factor-I receptor/human epidermal growth factor receptor 2 heterodimerization contributes to trastuzumab resistance of breast cancer cells. Cancer Res. 2005;65:11118-11128.

93. Lindemann K, Resau J, Nahrig J, et al. Differential expression of c-Met, its ligand HGF/SF and HER2/neu in DCIS and adjacent normal breast tissue. Histopathology. 2007;51:54-62.

94. Shattuck DL, Miller JK, Carraway KL, III, Sweeney C. Met receptor contributes to trastuzumab resistance of Her2-overexpressing breast cancer cells. Cancer Res. 2008;68:1471-1477.

95. Nakshatri H, Bhat-Nakshatri P, Martin DA, Goulet RJ Jr, Sledge GW Jr. Constitutive activation of NF-kappaB during progression of breast cancer to hormone-independent growth. Mol Cell Biol. 1997; 17:3629-3639.

96. Nakshatri H, Goulet RJ Jr. NF-kappaB and breast cancer. Curr Probl Cancer. 2002;26:282-309.

97. Cardoso F, Durbecq V, Laes JF, et al. Bortezomib (PS-341, Velcade) increases the efficacy of trastuzumab (Herceptin) in HER-2-positive breast cancer cells in a synergistic manner. Mol Cancer Ther 2006;5:3042-3051.

98. Molina MA, Codony-Servat J, Albanell J, Rojo F, Arribas J, Baselga J. Trastuzumab (herceptin), a humanized anti-Her2 receptor monoclonal antibody, inhibits basal and activated Her2 ectodomain cleavage in breast cancer cells. Cancer Res. 2001;61:4744-4749.

99. Nagy P, Friedlander E, Tanner M, et al. Decreased accessibility and lack of activation of ErbB2 in JIMT-1, a herceptin-resistant, MUC4-expressing breast cancer cell line. Cancer Res. 2005;65: 473-482

100. Fessler SP, Wotkowicz MT, Mahanta SK, Bamdad C. MUC1* is a determinant of trastuzumab (Herceptin) resistance in breast cancer cells. Breast Cancer Res Treat. 2009;118:113-124.

101. Palyi-Krekk Z, Barok M, Isola J, Tammi M, Szollosi J, Nagy P. Hyaluronan-induced masking of ErbB2 and CD44-enhanced trastuzumab internalisation in trastuzumab resistant breast cancer. Eur $J$ Cancer. 2007;43:2423-2433.

102. Bussolati G, Montemurro F, Righi L, Donadio M, Aglietta M, Sapino A. A modified Trastuzumab antibody for the immunohistochemical detection of HER-2 overexpression in breast cancer. $\mathrm{Br} J$ Cancer. 2005;92:1261-1267.

103. Sapino A, Montemurro F, Marchio C, et al. Patients with advanced stage breast carcinoma immunoreactive to biotinylated Herceptin are most likely to benefit from trastuzumab-based therapy: an hypothesis-generating study. Ann Oncol. 2007;18 1963-1968.

104. Hudelist G, Kostler WJ, Attems J, et al. Her-2/neu-triggered intracellular tyrosine kinase activation: in vivo relevance of ligand-independent activation mechanisms and impact upon the efficacy of trastuzumabbased treatment. Br J Cancer. 2003;89:983-991.

105. Liu PC, Liu X, LiY, et al. Identification of ADAM10 as a major source of HER2 ectodomain sheddase activity in HER2 overexpressing breast cancer cells. Cancer Biol Ther. 2006;5:657-664. 
106. Liu X, Fridman JS, Wang Q, et al. Selective inhibition of ADAM metalloproteases blocks HER-2 extracellular domain (ECD) cleavage and potentiates the anti-tumor effects of trastuzumab. Cancer Biol Ther. 2006;5:648-656.

107. Kostler WJ, Schwab B, Singer CF, et al. Monitoring of serum Her-2/neu predicts response and progression-free survival to trastuzumab-based treatment in patients with metastatic breast cancer. Clin Cancer Res. 2004;10:1618-1624.

108. Colomer R, Llombart-Cussac A, Lluch A, et al. Biweekly paclitaxel plus gemcitabine in advanced breast cancer: phase II trial and predictive value of HER2 extracellular domain. Ann Oncol. 2004;15:201-206.

109. Fornier MN, Seidman AD, Schwartz MK, et al. Serum HER2 extracellular domain in metastatic breast cancer patients treated with weekly trastuzumab and paclitaxel: association with HER2 status by immunohistochemistry and fluorescence in situ hybridization and with response rate. Ann Oncol. 2005;16:234-239.

110. Lennon S, Barton C, Banken L, et al. Utility of serum HER2 extracellular domain assessment in clinical decision making: pooled analysis of four trials of trastuzumab in metastatic breast cancer. J Clin Oncol. 2009;27:1685-1693.

111. Seidman A, Hudis C, Pierri MK, et al. Cardiac dysfunction in the trastuzumab clinical trials experience. J Clin Oncol. 2002;20: $1215-1221$.

112. Untch M, Muscholl M, Tjulandin S, et al. First-line trastuzumab plus epirubicin and cyclophosphamide therapy in patients with human epidermal growth factor receptor 2-positive metastatic breast cancer: cardiac safety and efficacy data from the Herceptin, Cyclophosphamide, and Epirubicin (HERCULES) trial. J Clin Oncol. 2010;28:1473-1480.

113. Seidman AD, Fornier MN, Esteva FJ, et al. Weekly trastuzumab and paclitaxel therapy for metastatic breast cancer with analysis of efficacy by HER2 immunophenotype and gene amplification. J Clin Oncol. 2001;19:2587-2595.

114. Guarneri V, Lenihan DJ, Valero V, et al. Long-term cardiac tolerability of trastuzumab in metastatic breast cancer: the M.D. Anderson Cancer Center experience. J Clin Oncol. 2006;24:4107-4115.

115. Romond EH, Perez EA, Bryant J, et al. Trastuzumab plus adjuvant chemotherapy for operable HER2-positive breast cancer. $N$ Engl $J$ Med. 2005;353:1673-1684.

116. Piccart-Gebhart MJ, Procter M, Leyland-Jones B, et al. Trastuzumab after adjuvant chemotherapy in HER2-positive breast cancer. $N$ Engl J Med. 2005;353:1659-1672.

117. Slamon D, Iermann W, Robert N, et al. Phase III Randomized Trial Comparing Doxorubicin and Cyclophosphamide Followed by Docetaxel $(\mathrm{AC} \geq \mathrm{T})$ with Doxorubicin and Cyclophosphamide followed by Docetaxel and Trastuzumab ( $\mathrm{AC} \geq \mathrm{TH})$ with Docetaxel, Carboplatin and Trastuzumab (TCH) in HER2neu Positive Early Breast Cancer Ppatients: BCIRG006 Study [abstract]. Cancer Res. 2009;69.

118. Joensuu H, Bono P, Kataja V, et al. Fluorouracil, epirubicin, and cyclophosphamide with either docetaxel or vinorelbine, with or without trastuzumab, as adjuvant treatments of breast cancer: final results of the FinHer Trial. J Clin Oncol. 2009;27:5685-5692.

119. Tan-Chiu E, Yothers G, Romond E, et al. Assessment of cardiac dysfunction in a randomized trial comparing doxorubicin and cyclophosphamide followed by paclitaxel, with or without trastuzumab as adjuvant therapy in node-positive, human epidermal growth factor receptor 2-overexpressing breast cancer: NSABP B-31. J Clin Oncol. 2005;23:7811-7819.

120. Perez EA, Suman VJ, Davidson NE, et al. Cardiac safety analysis of doxorubicin and cyclophosphamide followed by paclitaxel with or without trastuzumab in the North Central Cancer Treatment Group N9831 adjuvant breast cancer trial. J Clin Oncol. 2008;26:1231-1238.

121. Procter M, Suter TM, de AE, et al. Longer-term assessment of trastuzumab-related cardiac adverse events in the Herceptin Adjuvant (HERA) trial. J Clin Oncol. 2010;28:3422-3428.

122. McArthur HL, Chia S. Cardiotoxicity of trastuzumab in clinical practice. N Engl J Med. 2007;357:94-95.
123. Montemurro F, Redana S, Valabrega G, Martinello R, Aglietta M, Palmiero R. Trastuzumab-related cardiotoxicity in the herceptin adjuvant trial. J Clin Oncol. 2008;26:2052-2053.

124. Suter TM, Procter M, van Veldhuisen DJ, et al. Trastuzumabassociated cardiac adverse effects in the herceptin adjuvant trial. J Clin Oncol. 2007;25:3859-3865.

125. Telli ML, Hunt SA, Carlson RW, Guardino AE. Trastuzumab-related cardiotoxicity: calling into question the concept of reversibility. J Clin Oncol. 2007;25:3525-3533.

126. Cardinale D, Colombo A, Torrisi R, et al. Trastuzumab-induced cardiotoxicity: clinical and prognostic implications of troponin I evaluation. J Clin Oncol. 2010;28:3910-3916.

127. Ewer MS, Vooletich MT, Durand JB, et al. Reversibility of trastuzumabrelated cardiotoxicity: new insights based on clinical course and response to medical treatment. J Clin Oncol. 2005;23:7820-7826.

128. Munoz J, Sheqwara J, Arango B, Ali HY, Loutfi R, Weaver DW. The role of beta-blockers and ACE inhibitors in the prevention of trastuzumab-related cardiotoxicity [abstract]. J Clin Oncol (Meeting Abstracts). 2010;28:555

129. Buzdar AU, Ibrahim NK, Francis D, et al. Significantly higher pathologic complete remission rate after neoadjuvant therapy with trastuzumab, paclitaxel, and epirubicin chemotherapy: results of a randomized trial in human epidermal growth factor receptor 2-positive operable breast cancer. J Clin Oncol. 2005;23:3676-3685.

130. Gianni L, Eiermann W, Semiglazov V, et al. Neoadjuvant chemotherapy with trastuzumab followed by adjuvant trastuzumab versus neoadjuvant chemotherapy alone, in patients with HER2-positive locally advanced breast cancer (the NOAH trial): a randomised controlled superiority trial with a parallel HER2-negative cohort. Lancet. 2010;375:377-384.

131. Tanchiu E, Kaufman PA, Paik S, et al. registHER: a prospective, longitudinal cohort study of women with HER2 positive metastatic breast cancer [abstract]. J Clin Oncol (Meeting Abstracts). 2005;23:670.

132. Tripathy D, Kaufman P, Brufsky A, et al. registHER: treatment outcomes in patients with HER2-positive (HER2+), hormone receptorpositive (HR+) metastatic breast cancer (MBC) [abstract]. J Clin Oncol (Meeting Abstracts) 2009;27:1057.

133. Tripathy D, Slamon DJ, Cobleigh M, et al. Safety of treatment of metastatic breast cancer with trastuzumab beyond disease progression. J Clin Oncol. 2004;22:1063-1070.

134. Fountzilas G, Razis E, Tsavdaridis D, et al. Continuation of trastuzumab beyond disease progression is feasible and safe in patients with metastatic breast cancer: a retrospective analysis of 80 cases by the hellenic cooperative oncology group. Clin Breast Cancer. 2003;4:120-125.

135. Rabindran SK, Discafani CM, Rosfjord EC, et al. Antitumor activity of HKI-272, an orally active, irreversible inhibitor of the HER-2 tyrosine kinase. Cancer Res. 2004;64:3958-3965.

136. Burstein HJ, Sun Y, Dirix LY, et al. Neratinib, an irreversible ErbB receptor tyrosine kinase inhibitor, in patients with advanced ErbB2positive breast cancer. J Clin Oncol. 2010;28:1301-1307.

137. Awada A, Dirix L, Beck J, et al. Safety and efficacy of Neratinib (HKI-272) in combination with Vinorelbine in ErbB2+ metastatic breast cancer [abstract]. Cancer Res. 2009;69:5095.

138. Chow L, Gupta S, Hershman D, et al. Safety and efficacy of Neratinib (HKI-272) in combination with Paclitaxel in ErbB2+ metastatic breast cancer [abstract]. Cancer Res. 2009;69:5081.

139. Saura C, Martin M, Moroose R, et al. Safety of Neratinib (HKI-272) in combination with Capecitabine in patients with solid tumors: a Phase 1/2 study [abstract]. Cancer Res. 2009;69:5108.

140. Adams CW, Allison DE, Flagella K, et al. Humanization of a recombinant monoclonal antibody to produce a therapeutic HER dimerization inhibitor, pertuzumab. Cancer Immunol Immunother. 2006;55:717-727.

141. Franklin MC, Carey KD, Vajdos FF, Leahy DJ, de Vos AM, Sliwkowski MX. Insights into ErbB signaling from the structure of the ErbB2-pertuzumab complex. Cancer Cell. 2004;5: $317-328$. 
142. Cortes J, Baselga J, Petrella T, et al. Pertuzumab monotherapy following trastuzumab-based treatment: activity and tolerability in patients with advanced HER2-positive breast cancer [abstract]. J Clin Oncol (Meeting Abstracts). 2009;27:1022.

143. Baselga J, Gelmon KA, Verma S, et al. Phase II trial of pertuzumab and trastuzumab in patients with human epidermal growth factor receptor 2-positive metastatic breast cancer that progressed during prior trastuzumab therapy. J Clin Oncol. 2010;28:1138-1144.

144. Lewis Phillips GD, Li G, Dugger DL, et al. Targeting HER2-positive breast cancer with trastuzumab-DM1, an antibody-cytotoxic drug conjugate. Cancer Res. 2008;68:9280-9290.

145. Krop IE, Beeram M, Modi S, et al. Phase I study of trastuzumabDM1, an HER2 antibody-drug conjugate, given every 3 weeks to patients with HER2-positive metastatic breast cancer. J Clin Oncol. 2010;28:2698-2704
146. Miller K, Gianni L, Andre F, et al. A phase Ib/II trial of trastuzumabDM1 (T-DM1) with pertuzumab (P) for women with HER2-positive, locally advanced or metastatic breast cancer (BC) who were previously treated with trastuzumab (T) [abstract]. J Clin Oncol (Meeting Abstracts). 2010;28:1012.

147. Perez E, Dirix L, Kocsis J,et al. Efficacy and safety of TrastuzumabDM1 versus trastuzumab plus docetaxel in HER2-positive metastatic breast cancer patients with no prior chemotherapy for metastatic disease: preliminary results of a randomized multicenter, open labe phase 2 study (TDM4450G) [abstract]. Ann Oncol (meeting Abstracts). 2010; 21: viii2

\section{Publish your work in this journal}

Breast Cancer: Targets and Therapy is an international, peerreviewed open access journal focusing on breast cancer research, identification of therapeutic targets and the optimal use of preventative and integrated treatment interventions to achieve improved outcomes, enhanced survival and quality of life for the cancer patient.

\section{Dovepress}

View the full aims and scopes of this journal here. The manuscript management system is completely online and includes a very quick and fair peer-review system, which is all easy to use. Visit http:// www.dovepress.com/testimonials.php to read real quotes from published authors.

Submit your manuscript here: http://www.dovepress.com/breast-cancer---targets-and-therapy-journal 